Jarema Słowiak

Faculty of History

Jagiellonian University, Kraków, Poland

\title{
General Westmoreland: An Unfulfilled Hero Who Was Turned into a Scapegoat
}

\begin{abstract}
This article is dedicated to the most prominent American commander of the Vietnam War, or to be more precise, to the treatment of General William C. Westmoreland in modern American historiography. Ridiculed and accused of lying to the American public during his lifetime, General Westmoreland still remains one of the 'villains' of the Vietnam War. In recent years it has changed slightly, and now on the publishing market we can find books both attacking and defending the MACV commander and his decisions. However, mainstream historiography continues to judge him through the prism of the American trauma caused by the Vietnam War, and not his real merit and achievements. This article aims to dispel at least a few myths persisting both about General Westmoreland and his strategy to win 'an unwinnable conflict.'
\end{abstract}

Every American war has its symbols and heroes. While individual courage is appreciated and people like Audie Murphy ${ }^{1}$ are also remembered, those most strongly embedded in the collective consciousness are usually the commanders, since they are the individuals that had a decisive influence on the course and outcome of the conflict. They are identified with a particular war and the conflict is often viewed through their prism. However, sometimes it also goes the other way, and it is the general who is perceived through the prism of the war he participated in. The First World War had General Pershing. The Second World War is inseparably associated with names such as Eisenhower, Patton and MacArthur. In the public awareness, the latter, together with his iconic pipe, is also connected with the Korean War. The most traumatic American conflict of the twentieth century - the Vietnam War - also has a commander that became its symbol.

General William Childs Westmoreland, commander of the Military Assistance Command Vietnam (MACV) in the years 1964-1968, was not the only American

1 One of the most decorated American combat soldiers of WWII (Web. 19 June 2015. http:// www.arlingtoncemetery.mil/Explore-the-Cemetery/Notable-Graves/ProminentMilitary-Figures/Audie-Murphy). 
commander-in-chief in Vietnam, and it was not the only war in which he took part. This conflict, however, defined his place in history. ${ }^{2}$ The years of his service in Vietnam coincided with the period that saw groundbreaking developments for this war - the direct intervention of U.S. forces in 1965, their escalating activities in the next two years, and the Tet Offensive in 1968. Westmoreland arrived in South-East Asia as a candidate for a true American hero - relatively young, with an impeccable presence and excellent service record, appearing on the covers of American magazines. ${ }^{3}$ However, he returned to the United States already in disgrace, burdened with the stigma of a commander who was unable to win the war and who had lied to the public, a stigma which burdened him for the rest of his life.

Westmoreland was born in an upper middle-class family from South Carolina. ${ }^{4}$ From an early age, his interests gravitated toward the military. In his youth, he was a distinguished member of the Boy Scouts, and after being educated at The Citadel ${ }^{5}$ he was accepted into West Point (Sorley 1-4). There, he was an outstanding cadet ${ }^{6}$ in the class that also gave U.S. forces commanders such as Creighton Abrams and Benjamin O. Davis Jr., the first black general in the U.S. Air Force. After graduation, Westmoreland was posted in an artillery unit. During World War II, he took part in fighting in North Africa, Sicily and France. After the end of the global conflict, he reclassified into a paratrooper and later commanded the $187^{\text {th }}$ Airborne Combat Team during the Korean War (Westmoreland 25). After returning to the United States, he completed the management program at Harvard Business School, and became the secretary of the General Staff in the Pentagon. In 1960, he was named the superintendent of West Point. He held that position up to late 1963 when he learned that his next assignment would be in MACV. He seemed, therefore, to have all the characteristics predisposing him to the role of a hero who would lead Americans to victory in Vietnam (Karnow 345).

He arrived in Saigon in January 1964, like the deputy of the MACV commander, General Paul Harkins. However, from the beginning it was known that he was foreseen as a successor for his superior, who was criticized in Washington for undue optimism in his reports (Cosmas, MACV...1962-1967 123). The other problem was a complete lack of cooperation between Harkins and his nominal superior, the ambassador Henry Cabot Lodge Jr., caused by their grave disagreement on the advisability of the Diem coup in November 1963 (Westmoreland 65). Their relations

2 It is especially evident when we look at the general's obituaries: Eric Pace, General Westmoreland Dies; Led U.S. in Vietnam, "The New York Times" 19 July 2005; Patricia Sullivan, General Commanded Troops in Vietnam, "The Washington Post" 19 July 2005; Jenny Booth, Commander of US forces in Vietnam dies, "The Times" (London) 19 July 2005.

3 He was chosen as 'Man of the Year' for 1965 by Time magazine (7 January 1966), and also appeared on the cover of the magazine on 19 February 1965 and 5 May 1967.

4 The biographical info about General Westmoreland in this article was drawn from the MACV commander's autobiography (Westmoreland), biographies by Lewis Sorley (Westmoreland: The General Who Lost Vietnam) and Samuel Zaffiri (Westmoreland: A Biography of General William C. Westmoreland).

5 A public, coeducational college established as the Military College of South Carolina in 1842.

6 He received the Pershing Sword, "given each year to the most militarily proficient ca$\operatorname{det}^{\prime \prime}$ (Keeney). 
deteriorated to the point that Secretary McNamara wrote: "Lodge sends in reports with major military implications without showing them to Harkins, and does not show Harkins important incoming traffic" (Cosmas, MACV...1962-1967 122). Harkins left Vietnam in July and Westmoreland assumed command of MACV. The first years of his leadership in Vietnam appeared to confirm the expectations associated with his person. Although direct intervention by U.S. forces and their drastic expansion proved necessary, he managed to stop the progress of the communists, went to a counter-offensive and took the initiative from the enemy. In 1965, the political situation in South Vietnam - pushed into a spiral of chaos and anarchy after the assassination of Ngo Dinh Diem in November 1963 - also finally stabilized (Westmoreland 92-98). The Ky-Thieu ${ }^{7}$ tandem was able to stop the vicious cycle of coups and gave hope for a gradual restoration of normalcy in the South, which was best expressed by the smooth conduct of the elections in 1966 and 1967 (Westmoreland 188, 221).

These developments caused profound anxiety in $\mathrm{Hanoi}^{8}$, where two factions with different ideas of how to continue the war clashed with each other. The first, represented i.a. by General Vo Nguyen Giap, was in favor of continuing the protracted guerrilla warfare in the South and building socialism in the North. The second faction, led by Party General Secretary Le Duan, demanded throwing all forces to the armed 'liberation of the South,' even at the expense of the development of the North. In the struggle for power, the second option prevailed, and in mid-1967 it was decided to conduct the General Offensive/General Uprising in the South the following year (Nguyen 19-25). The military strike aimed at cities was supposed to provoke an uprising of the oppressed masses and the collapse of the government, which in turn would force the Americans to withdraw from the country. At the same time, General Giap, who was designated as the organizer of the entire project, had made plans to wage a pitched battle for the American fortified camp of Khe Sanh, hoping to achieve success similar to the victory at Dien Bien Phu fourteen years earlier. ${ }^{9}$

The Tet Offensive proved to be a military flop, like the siege of Khe Sanh. Communist troops were bloodily repelled and failed to hold on for longer anywhere besides the ancient imperial city of Hue. ${ }^{10}$ Even worse for Hanoi, South Vietnamese society

7 Nguyen Cao Ky was a commander of the Vietnam Air Force, who, along with General Nguyen Van Thieu, formed the leadership of a military junta that finally brought an end to the coup cycle in Vietnam. Ky became the prime minister, while Thieu assumed the post of president (Benken 45).

8 Vietnamese communists hoped that after the death of Ngo Dinh Diem they would manage to destroy the South Vietnamese administration and conquer the country before the Americans decided to directly intervene. The political chaos also gave them hope of self-destruction of the Republic of Vietnam or a rise to power of neutral forces willing to deal with the North (Moyar 286).

9 Giap was skeptical about the prospects of success of the General Offensive, the planning of which was given to him only after the mysterious death of its original mastermind, General Nguyen Chi Thanh. Suggestions appearing in American literature that the siege of Khe Sanh was just a clever distraction from the upcoming offensive cannot withstand confrontation with the facts, and seem to be repeating the communist narrative that sought to obscure the defeat of this 77-day siege (Benken 186-187; Słowiak, "Khe Sanh..." 33-65).

10 The Americans and the South Vietnamese retook the city after three weeks of fierce street fighting. For more information, see: (Benken; Willbanks). 
was not in the least willing to revolt. Destruction and death caused by attacks on the city actually led to an increase of support for the authorities (Willbanks 81). The offensive, however, enjoyed great success on the other side of the ocean. American public opinion, up to this point convinced that the opponent was close to collapse, was shocked by the grand scale of the communist attack. ${ }^{11}$ President Lyndon Johnson's administration was accused of lying to the American people. ${ }^{12}$ General Westmoreland was also criticized, since in the second half of 1967, together with Ambassador Ellsworth Bunker, he had made a tour around the United States persuading the American public that the enemy was close to defeat. ${ }^{13}$ In addition, the MACV commander was accused of being oblivious to the enemy's preparations for the offensive and poor judgement when it broke out. As a result, when it was announced that Westmoreland would return to the U.S. to take the position of the Chief of Staff of the U.S. Army, it was widely considered a 'kick upstairs,' although the rotation of the MACV commander had already been agreed upon in 1967 (Cosmas, MACV... 1968-1973 105). In his new role, Westmoreland sought to reform the army on the basis of his own experience from Vietnam ${ }^{14}$ and to lead it in a new direction, based on voluntary enlistment. After leaving the army, he tried to run for the office of governor of South Carolina in 1974, but failed. Two years later, he published his autobiography. For the rest of his life he was strongly committed to the defense of American intervention in Vietnam and the affairs of veterans of this war (Sorley 296).

The most common and dominant accusations against Westmoreland in American historiography are attrition strategy and big unit war, closely tied with his person (Anderson 57). This narrative holds that the U.S. military did not understand the complex realities of the conflict in which they had become engaged and that, being intellectually unable to meet this challenge, the commander of MACV decided on a basically primitive solution, which was to kill the largest possible number of enemy soldiers to exhaust the Communists and thus force them to make concessions (Sorley 91). This interpretation is strongly rebutted by Gregory A. Daddis. He points out that the U.S. military closely followed the course of the fighting in Vietnam, and they were by no means blind to the multi-dimensionality of the conflict and the mixing of military, social and political issues in guerrilla warfare (Daddis, Westmoreland's War... 34). Like Graham A. Cosmas ${ }^{15}$, Daddis believes that MACV

11 The Tet Offensive was full of shocking and symbolic events, such as the attack on the U.S. embassy in Saigon and the street execution of a Viet Cong officer dressed in civilian clothes by General Nguyen Ngoc Loan. Although they were not very important from the military perspective, they created a powerful narrative about the offensive ("Iconic Picture Photographer Dies." Web. 19 June 2015. http:/ / news.bbc.co.uk/2/hi/americas/3672060.stm).

12 Tom Wicker. "Illusions and Deceptions." The New York Times, 11 February 1968.

13 The case would haunt Westmoreland much later, when in 1982 he sued CBS for the allegation that he had deliberately underestimated Communist troop numbers in 1967 in order to preserve U.S. troop morale and domestic support for the war. While the trial was in progress, Westmoreland and CBS settled for an apology (Daddis, Westmoreland's War... XXI).

14 For example, he commissioned the report Study on Military Professionalism, which had a huge impact on future army policies. The report is available on the internet: Web. 2 June 2015. http://www.dnipogo.org/fcs/pdf/professionalism_study_1970.pdf.

15 The author of a two-tome monography of MACV: (Cosmas. MACV ...1962-1967; Cosmas, MACV ...1968-1973). 
and its commander did not become overconfident by the firepower at their disposal, and summing up the complex and multi-faceted strategy developed by MACV with one catchphrase in the form of 'attrition' is an unacceptable generalization (Daddis, Westmoreland's War... 9-11).

In reality, General Westmoreland faced a very difficult task by assuming command of MACV: with limited resources ${ }^{16}$ he was expected to defeat the communist guerrillas in Vietnam, stop the infiltration from the North, stabilize the political situation in the South, and restore Saigon's control over the territory of its own country. He was expected to be successful despite the political constraints that prevented him from striking the Ho Chi Minh Trail in Laos and enemy sanctuaries in Cambodia, or attacking the Democratic Republic of Vietnam. ${ }^{17}$ The strategy developed by the MACV commander sought to include the military, social and political conditions of Vietnam, while staying within the framework imposed by the civilian politicians.

The plan devised by Westmoreland was divided into three phases:

Phase One: Commit those American and Allied forces necessary "to halt the losing trend" by the end of 1965 .

Phase Two: "During the first half of 1966," take the offensive with American and Allied forces in "high priority areas" to destroy enemy forces and reinstitute pacification programs.

Phase Three: If the enemy persisted, he might be defeated and his forces and base areas destroyed during a period of a year and a half following Phase II (Westmoreland 142).

Even from this very general scheme we can see that the MACV commander wanted to use combat operations as a means of resuming pacification efforts. His troops were to become a shield protecting the non-combat activities aimed at the South Vietnamese civilian population, in order to bring it back under government control. It is true that he wanted to bring the battle to the enemy, but it is equally true that after the fall of Diem in November 1963, the Communists were bringing the battle upon themselves. ${ }^{18}$ Westmorland detractors argue that the body count was

16 It should be remembered that the size of the American forces in Vietnam grew gradually, along with the escalating infiltration of South Vietnam by the Vietnam People's Army troops from the North by the Ho Chi Minh Trail (Moyar 370).

17 The U.S. administration believed that such an escalation of the war would draw Communist China into it. In reality, Hanoi was constantly worried about the potential American assault above the $17^{\text {th }}$ parallel, which would most likely lead to a withdrawal of NVA units from South Vietnam (Tin 54).

18 The $9^{\text {th }}$ Plenum of the Central Committee of the Vietnamese Workers' Party, deliberating in December 1963, decided that in the face of the failure of the 'puppet regime,' the United States, faced with the dilemma of pulling out of Vietnam or proceeding with a limited war and bringing in American troops, had chosen the second option. As a response, Hanoi decided to quickly escalate the war, hoping to topple South Vietnam before the United States could bring its full power into the equation (The Central Committee's $9^{\text {th }}$ Plenum Resolution Discussing the International Situation December 1963. The document is available on the internet: The Vietnam Center and Archive, Texas Tech University. Web. 10 June 2015. http://www.vietnam. ttu.edu). 
only an indicator of success in the attrition strategy (Anderson 99), and that in his pursuit of this goal, he "ignored two other crucial aspects of the war, improvement of South Vietnam's armed forces and pacification" (Sorley 91).

However, in reality, the MACV commander never lost sight of the political and social aspect of the war, writing to his superior that besides defeating the enemy, his main mission goals were "expanding security in populated and productive areas, and encouraging and supporting all aspects of nation-building," in accordance with the overall American policy of that time (Daddis, Westmoreland's War... 84). He also loathed the common usage of the term 'body count' (Westmoreland 273), seeing it as a dehumanization of individuals fighting in the war (Keeney 1999).

There were, and still are, opinions that there were better ways to deal with the situation in Vietnam. Westmoreland critics especially like to point out the enclave theory, advocated by retired General James M. Gavin and the American ambassador to Vietnam, Maxwell Taylor (Anderson 166). However, there is one fatal flaw in the enclave strategy - it locked Americans in confined zones, giving initiative to the enemy in a situation when the Communists were on the offensive and winning all around the country. A different alleged alternative to Westmoreland's strategy was the combined action program advocated by the Marines, which called for organization of combined action platoons (CAP) that would mingle with the populace and provide on-spot security (Tucker 126). However, the Marines' approach on populace security was not actually all that different from the priorities of the MACV strategy, but at the same time their focus on localized operations allowed the main enemy forces to operate with relative ease (Daddis, Westmoreland's War... 79-80).

But while military operations were necessary to stop the progress of the Communists and push them out from already occupied territories, Westmoreland never lost sight of the fact that to win the war, pacification of the countryside and civic action aimed at the civilian populace were also necessary (Westmoreland 142-155). The attention which he attached to this aspect - clearly showing that he understood that it was not a simple, straightforward war in the style of the Second World War - is visible even in the newspaper articles of that time. ${ }^{19}$ Despite the difficulties, Westmoreland managed in Vietnam to create from scratch the infrastructure capable of accepting and serving hundreds of thousands of troops in subsequent years (Westmoreland 185-187). At the same time, American troops conducted combat operations that pushed the enemy to the defensive and forced Hanoi to take a desperate step, which in fact was the Tet Offensive. Westmoreland also did not forget about civic action aimed at the South Vietnamese population, treating it as an integral part of his strategy (Daddis, Westmoreland's War... 120). The positive results achieved during the tenure of his successor were largely thanks to Westmoreland's work (Daddis, Westmoreland's War... 170). If the strategy had been at fault, Creighton Abrams would not have claimed that it was sound or have told the president: "I don't feel we need to change strategy." 20

19 Charles Mohr. "U.S. Vietnam Force Told to Protect Civilian Lives." The New York Times, 18 September 1965.

20 Notes of the President's Meeting with General Earle Wheeler, JCS and General Creighton Abrams, 26 March 1968. FRUS, vol. VI: 459-465. 
Accusations of alleged intellectual and character deficiencies (Sorley 209) or highlighting attrition strategy as something pejorative is much less credible if we take a look at Westmoreland's career before his service in Vietnam. Having graduated with honors from West Point, he served with distinction in World War II, showing himself as a shrewd commander with the ability to improvise and act outside the box. ${ }^{21}$ In the 1950s, serving as secretary of the Chief of Staff of the U.S. Army and then as commander of the $101^{\text {st }}$ Airborne Division, he was able to observe the introduction of a pentomic division concept from both the theoretical and practical sides (Westmoreland 31-32). While he led the Screaming Eagles, Westmoreland organized a special divisional school called RECONDO, aimed at training paratroopers in commando-like skills. When he became the superintendent of his alma mater, West Point, he initiated an overhaul of the curriculum with emphasis on counter-insurgency and encouraged the cadets to take courses in history, psychology and political science (Daddis, Westmoreland's War... 28). Sensing that in the future he could be sent to Vietnam, he read extensively about the communist insurgency and sponsored a counter-insurgency conference at West Point with Walt W. Rostow as keynote speaker (Westmoreland 39). General Westmoreland definitely understood that the conflict in Vietnam was different from anything the U.S. armed forces had faced up until this point, and was more than prepared to wrestle with this problem on an intellectual level. ${ }^{22}$

While the strategy developed by Westmoreland, combining counter-insurgency with civic and military action, and gaining support from the South Vietnam population, was sound, the strategy alone was not equal to winning the war in surroundings as complex as Vietnam. But this should not change the evaluation of the MACV commander himself, considering the various restrictions constraining him (Daddis, Westmoreland's War... 82). However, the trauma of the Tet Offensive, followed by losing the war itself, distorted the American perception of General Westmoreland. He is still negatively evaluated through the prism of the Vietnam War's final outcome despite his lack of influence on it, and in complete isolation from the facts, often to the level of a "veiled attempt at character assassination," as Lewis Sorley's book Westmoreland: The General Who Lost Vietnam was rightly called ${ }^{23}$ (Daddis, Westmoreland's War... 205). Unfortunately, the general fell victim to an often occurring situation in which authors tried to describe a complex phenomenon by giving simple answers. Hence the accusations of a coarse strategy, misunderstanding the enemy, and even intellectual limitations. Just as the victory has its heroes, defeat must have its villains. America lost the war in Vietnam and needed someone to focus its

21 During the fighting on Sicily, as a commander of an artillery battalion he proposed attaching his unit and its machine park to the $82^{\text {nd }}$ Airborne Division, to provide paratroopers with better fire support and mobility (they lacked their own trucks). It is worth noting that Lewis Sorley tried to vilify that situation as "freelancing" on Westmoreland's part (Sorley 17).

22 There are, however, authors who credit Westmoreland's steady rise in the U.S. army more to his "influential patrons and the skillful use of talented staff assistants" than his own talents, claiming also that he was more of a bureaucrat and manager than a tactician and strategist (Turley 98).

23 Sorley presents the idea that the commander of MACV single-handedly lost the war. For a more elaborate critique of Sorley's work, see: (Daddis, "On Lewis Sorley..." 99-105; Słowiak, "In the Search for a Scapegoat..." 299-303). 
anger at, thus Westmoreland became a convenient scapegoat along with President Johnson, who wanted to be remembered for his Great Society project but is associated today with a war inherited from his predecessor.

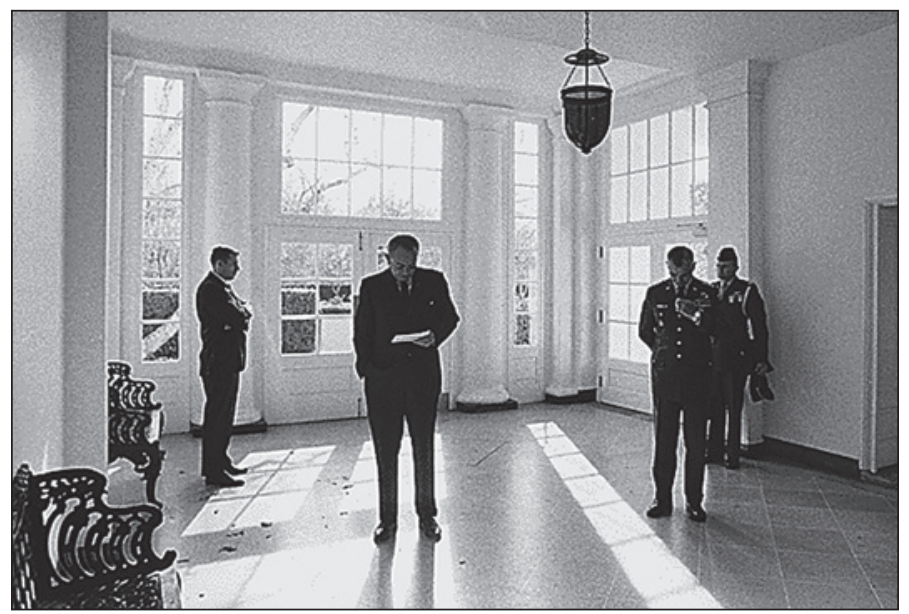

The two 'villains' of the Vietnam War: President Lyndon B. Johnson reads a report as General Westmoreland waits next to him (The National Archives)

Perhaps the best punchline of the real assessment of General Westmoreland is an incident from the Welcome Home Parade, organized in 1986 by the Vietnam War veterans' community in Chicago. Some organizers feared the reaction of the assembled people to the presence of the former MACV commander, serving as a parade marshal, considering him to be as unpopular as the war itself. But 200,000 veterans, seeing their former commander again, reacted instead with sympathy and enthusiasm. Unit after unit stopped to salute him, up to the point when organizers had to ask them to move along because they were blocking the rest of the procession. ${ }^{24}$

\section{References}

Documents and sources:

The Central Committee's $9^{\text {th }}$ Plenum Resolution Discussing the International Situation December 1963. [Document acquired from the webpage: The Vietnam Center and Archive, Texas Tech University. Web. 10 June 2015. http:/ / www.vietnam.ttu.edu].

Foreign Relations of the United States. Diplomatic Papers: 1964-68, volume 6.

\section{Press:}

Chicago Tribune 1986.

The New York Times 1965, 1968, 2005.

Time 1965, 1966, 1967.

The Times 2005.

The Washington Post 2005.

24 William Mullen. “At Peace, At Last.” Chicago Tribune, 17 August 1986. 


\section{Articles:}

Daddis, Gregory A. “On Lewis Sorley Westmoreland: The General Who Lost Vietnam.” Parameters 2011: Autumn: 99-105.

Keeney, Craig M. "A Chronicle of Extraordinary Service: The Military Career of Gen. William Childs Westmoreland." Caroliniana Columns. Newsletter of the University South Caroliniana Society 1999: Autumn. Web. 18 June 2015. http://library.sc.edu/socar/uscs/ 99autm/99front.html.

Nguyen, Lien-Hang T. “The War Politburo: North Vietnam's Diplomatic and Political Road to the Tot Offensive." Journal of Vietnamese Studies 1: 2006 (1/2).

Słowiak, Jarema. "In the Search for a Scapegoat. On the Margin of the Book: Lewis Sorley, Westmoreland: The General Who Lost Vietnam." Prace Historyczne 140: 2013 (3): 299-303.

Słowiak, Jarema. "Khe Sanh - niespełnione Dien Bien Phu Drugiej Wojny Indochińskiej." Studia nad wojnami w Indochinach, tom 1. Ed. Przemysław Benken. Oświęcim: Napoleon V, 2013: 33-65.

Tin, Bui. "Fight for the Long Haul." Rolling Thunder in a Gentle Land. The Vietnam War Revised. Ed. Andrew Wiest. Oxford, New York: Osprey, 2006.

\section{Books:}

Anderson, David L. The Columbia Guide to the Vietnam War. New York: Columbia University Press, 2002.

Benken, Przemysław. Ofensywa Tet 1968. Studium militarno-polityczne. Szczecin: Instytut Pamięci Narodowej - Komisja Ścigania Zbrodni przeciwko Narodowi Polskiemu. Oddział, 2014.

Bradley, Mark P. Vietnam at War. New York: Oxford University Press, 2009.

Cosmas, Graham A. MACV. The Joint Command in the Years of Escalation, 1962-1967. Washington: Center of Military History, United States Army, 2006.

Cosmas, Graham A. MACV. The Joint Command in the Years of Withdrawal, 1968-1973. Washington: Center of Military History, United States Army, 2006.

Daddis, Gregory A. Westmoreland's War. Reassessing American Strategy in Vietnam. Oxford, New York: Oxford University Press, 2014.

Isserman, Maurice. Vietnam War. New York: Facts on File, 2003.

Karnow, Stanley. Vietnam. A History. New York: Viking Press, 1983.

Moyar, Mark. Triumph Forsaken, The Vietnam War 1954-1965. Cambridge: Cambridge University Press, 2006.

Sorley, Lewis. Westmoreland: The General Who Lost Vietnam. New York, Boston: Houghton Mifflin Harcourt, 2011.

Tucker, Spencer C. Vietnam. London: UCL Press, 1999.

Turley, William S. Second Indochina War. Lanham, Boulder, New York, Toronto, Plymouth: Rowman \& Littlefield Publishers, 2009.

Westmoreland, William C. A Soldier Reports. New York: Doubleday, 1976.

Wiest, Andrew (ed.). Rolling Thunder in a Gentle Land. The Vietnam War Revised. Oxford, New York: Osprey, 2006.

Willbanks, James H. The Tet Offensive: A Concise History. New York: Columbia University Press, 2007.

Zaffiri, Samuel. Westmoreland: A Biography of General William C. Westmoreland. New York: Morrow, 1994.

\section{Internet:}

Arlington National Cemetery. Web. 18 June 2015. http:/ / www.arlingtoncemetery.mil.

British Broadcasting Corporation. Web. 18 June 2015. http:/ / www.bbc.com/. 
Defense and National Interest. Web. 4 June 2015. http:/ / www.dnipogo.org.

The National Archives. Web. 4 June 2015. http:/ / www.archives.gov/.

U.S. Department of State Office of the Historian. Web. 29 May 2015. http:/ / history.state.gov.

The Vietnam Center and Archive, Texas Tech University. Web. 29 May 2015. http://www.viet nam.ttu.edu. 